\title{
TNF- $\alpha$ genetic polymorphisms and its expression in Egyptian rheumatoid arthritis patients
}

\author{
Afaf K. Mousa ${ }^{1}$, Ahmed M. Ghoneim ${ }^{1}$, Noha B. El-Mashad ${ }^{2}$, Ahmed E. El-Ghobashy ${ }^{1}$ \\ ${ }^{1}$ Zoology Department, Faculty of Science, Damietta University, New Damietta, Egypt \\ ${ }^{2}$ Clinical Pathology Department, Faculty of Medicine, Mansoura University, Mansoura, Egypt \\ Email address: \\ mousa.afaf@yahoo.com (A. Mousa),am_ghoneim@du.edu.eg (A. Ghoneim),nmashad@hotmail.com (N. El-Mashad), \\ ahmad10@du.edu.eg (A. El-Ghobashy)
}

\section{To cite this article:}

Afaf K. Mousa, Ahmed M. Ghoneim, Noha B. El-Mashad, Ahmed E. El-Ghobashy. TNF- $\alpha$ Genetic Polymorphisms and its Expression in Egyptian Rheumatoid Arthritis Patients. American Journal of Life Sciences. Vol. 2, No. 4, 2014, pp. 234-240.

doi: 10.11648/j.ajls.20140204.17

\begin{abstract}
Rheumatoid arthritis (RA) is a complex, multifactorial, inflammatory disease that affects more than 1.5 million adults. The current study aimed to investigate whether there is an association between either $-376 \mathrm{G} / \mathrm{A}$ or $-238 \mathrm{G} / \mathrm{A}$ polymorphisms of TNF- $\alpha$ promoter and the risk of RA in Egyptian patients, and investigate whether these polymorphisms are linked to TNF- $\alpha$ expression. DNA from 54 clinically confirmed RA patients and 24 apparently healthy individuals was genotyped by RFLP technique. Some samples were selected for semi-quantitative measurement of TNF- $\alpha$ mRNA expression. For the -376 polymorphism, no polymorphism was recorded in this site neither in RA patients nor in the apparently healthy individuals. This indicated the wide distribution of the wild type GG genotype among Egyptians. For the -238 G/A polymorphism, data indicated that $77.8 \%$ of RA patients were of the genotype GG and $22.2 \%$ were heterozygous (GA), while $91.7 \%$ of the apparently healthy individuals were of the genotype GG and 8.3\% were heterozygous (GA). The homozygous genotype AA was not recorded in any RA or healthy subject. There was no statistically significant difference in the genotype distribution between RA patients and the apparently healthy individuals. Also, there was no statistically significant difference in either the $\mathrm{G}$ or A allele distribution between the RA group and the group of healthy subjects. Semi-quantitative PCR on some samples revealed a statistically significant increase in the relative expression of TNF- $\alpha$ mRNA in RA patients compared to healthy subjects. Based on these data, we conclude that $-238 \mathrm{G} / \mathrm{A}$ and $-376 \mathrm{G} / \mathrm{A}$ polymorphisms can not be considered as risk factors for RA among Egyptians and the increased expression of TNF- $\alpha$ in Egyptian RA patients is not linked to these polymorphisms. Therefore, Egyptian RA patients may have different genetic or environmental factors contributing to the pathogenesis of RA and further studies are necessary to search for other genetic polymorphisms and/or genes that contribute to the increased expression of TNF- $\alpha$ and hence the pathogenesis of RA in Egyptian patients.
\end{abstract}

Keywords: TNF- $\alpha$, Cytokine, Polymorphism, Expression, Susceptibility, Rheumatoid Arthritis

\section{Introduction}

Rheumatoid arthritis (RA) is a chronic, progressive, inflammatory autoimmune disease that is associated with articular, extra-articular and systemic effects [1]. RA is estimated to affect 1.5 million adults [2] and its sufferers are typically young (20 to 30 years age). RA incidence peaks at 35 to 50 years of age $[2,3]$ and is higher in women [2] with a higher lifetime risk (3.6\%) compared to men (1.7\%) [4]. Genetic and environmental factors are thought to contribute to susceptibility to RA initiation as well as severity of disease course [5]. The orchestrated interaction of proinflammatory cytokines, $\mathrm{T}$ cells and $\mathrm{B}$ cells plays key roles in the pathophysiology of RA [6, 7]. Among the cytokines involved is the tumor necrosis factor- $\alpha$ (TNF- $\alpha$ ) that plays an important role in the inflammatory and immune responses in several diseases, including RA [8]. TNF- $\alpha$ has been implicated in the stimulation of $\mathrm{T}$ cell immune response, upregulation of proteolytic enzymes, prostaglandins and chemokines, and over expression of adhesion, or HLA class II molecules in the pathogenesis of RA [9]. TNF- $\alpha$ production shows a wide variation, with high- and low-producer phenotypes present in humans [10], pointing to the influence of genetic variation on the regulation of TNF- $\alpha$ circulating levels. The promoter area of 
the TNF- $\alpha$ gene contains some single nucleotide polymorphisms (SNPs) which control the activity of the promoter and the resulting mRNA and protein levels [11]. Some studies in many parts of the world have addressed the issue of TNF- $\alpha$ gene promoter SNPs and RA outcome. The published data indicates the possible existence of TNF- $\alpha$ gene promoter variants that act as markers for disease severity and response to treatment in RA [12-14]. Out of the known polymorphisms in TNF- $\alpha$ gene promoter, only -308 G/A polymorphism has been addressed in Egyptian RA patients by Mosaad et al. [15]. The current study aimed to investigate (1) whether there is an association between either the $-376 \mathrm{G} / \mathrm{A}$ or $-238 \mathrm{G} / \mathrm{A}$ polymorphisms of TNF- $\alpha$ promoter and RA in Egyptian patients and (2) whether these polymorphisms are linked to the expression level of TNF- $\alpha$.

\section{Materials and Methods}

\subsection{Blood Sampling and DNA Extraction}

Peripheral blood samples were collected in EDTA-rinsed vacuotainer tubes by venipuncture from the arm vein of 54 clinically confirmed-RA subjects and 24 apparently healthy individuals in Mansoura University Hospital after providing informed consent. Genomic DNA was extracted from all blood samples by Gene JET ${ }^{\mathrm{TM}}$ Genomic DNA Purification Kit (\#K0722) according to the manufacturer's instructions and the purified DNA was either immediately used in downstream applications or stored at $-20^{\circ} \mathrm{C}$.

\subsection{Restriction Fragment Length Polymorphism (RFLP)}

All DNA samples extracted from RA patients and healthy controls were subjected to PCR to amplify 2 different regions of the TNF- $\alpha$ gene promoter. To investigate -376 G/A polymorphism, we used the forward primer 5'-AGTTCTATCTTTTTCCTGCATCCTGTCTGGAT-3'an $\mathrm{d}$ the reverse primer 5'-ATCCTCCCTGCTCCGATTCC-3' and to investigate $-238 \mathrm{G} / \mathrm{A}$ polymorphism, the forward primer 5'-AGAAGACCCCCCTCGGAACC-3' and the reverse primer 5'-ATCTGGAGGAAGCGGTAGTG-3'were used. All PCR reactions were performed and visualized as previously described [16]. PCR products of all subjects were restricted with FokI enzyme (\#FD2144) for investigating -376 G/A polymorphism and with MspI enzyme (\#ER0542) for investigating $-238 \mathrm{G} / \mathrm{A}$ polymorphism. Both restriction reactions were performed in a $30 \mu \mathrm{l}$ scale reaction as described before [16] with the exception of $15 \mathrm{~min}$. digestion time in case of Fast digest FokI. Restriction reactions were run side by side with an equivalent amount of undigested PCR reaction mixture in 5\% agarose gels for 50 min in TBE buffer and the gels were stained and photographed.

\subsection{Semi-Quantitative Measurement of TNF-a Gene Expression}

RNA was extracted from the white blood cells of 14 RA patients and 7 healthy subjects by the use of Gene JET ${ }^{\mathrm{TM}}$
RNA extraction kit (\#K0731, Fermentas) according to the manufacturer's instructions. Purified RNA preparations were converted into first strand cDNA by the use of

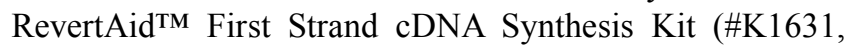
Fermentas). Synthesized cDNA was diluted and amplified by Maxima Hot start Master mix (Fermentas) for 30 cycles using newly designed TNF- $\alpha$ specific primers (forward: 5'-CTTCTCCTTCCTGATCGTGG-3' and reverse: 5'-CCCTGGGGAACTCTTCCCTCT-3') and the GAPDH specific primers (Forward: 5'-CAAGGTCATCCATGACAACTTTG-3' and reverse: 5'-GTCCACCACCCTGTTGCTGTAG-3'). TNF- $\alpha$ and GAPDH amplification products of the same sample were loaded together in the same well of the gel. TNF- $\alpha$ amplicons were quantitated relative to GAPDH amplicons using Image $\mathrm{J}$ software.

\section{Results}

\subsection{Genotype Frequencies}

To investigate the association of TNF- $\alpha$ gene polymorphisms with the risk of RA, DNA was extracted from the blood of 54 clinically confirmed RA patients and 24 apparently healthy subjects; and RFLP technique was used to study the $\mathrm{G}$ to A transition at the two sites -376 and -238 .

For studying $-376 \mathrm{G} / \mathrm{A}$ polymorphism, the region spanning the nucleotides -588 to -405 of the TNF- $\alpha$ gene promoter region was amplified by PCR which resulted in a 184 bp product as expected (Fig. 1A, lanes P). The amplified PCR products from RA patients and healthy individuals were digested with the restriction enzyme FokI and the restriction reactions were run parallel to the undigested PCR products on the same gels (Fig. 1A, lanes R). In all the samples of both RA and healthy subjects, a single band of approximately $146 \mathrm{bp}$ resulted from FokI restriction digestion. This digestion pattern is reminiscent of the complete digestion of PCR products and the expected small $38 \mathrm{bp}$ band could not be resolved on the gel. These results indicate that both clinically confirmed RA patients and apparently healthy individuals were all of the wild type GG genotype (Fig. $1 \mathrm{~A}$ ).

To investigate the $-238 \mathrm{G} / \mathrm{A}$ polymorphism, the region spanning the nucleotides -438 to -287 of the TNF- $\alpha$ gene promoter region was amplified by PCR which resulted in a 152 bp product as expected (Fig. 1B, lanes $\mathrm{P}$ ). The amplified PCR products from all subjects were digested with the restriction enzyme $M s p I$ and the restriction reactions were run parallel to the undigested PCR products on the same gels (Fig. 1B, lanes R). In 12 samples from RA patients, two fragments of approximately $152 \mathrm{bp}$ and $132 \mathrm{bp}$ resulted from MspI digestion. In the remaining 42 RA samples, a single band of about 132 bp resulted from MspI digestion. This digestion pattern is reminiscent of the genotype GA of the 12 RA patients and the GG genotype of the remaining $42 \mathrm{RA}$ patients and the expected small $20 \mathrm{bp}$ band could not be resolved on the gel. MspI restriction pattern of the 24 
apparently healthy individuals indicated that 2 healthy subjects were of the GA genotype while the other 22 subjects were of the GG genotype.

Thus, the homozygous GG genotype was detected in $77.8 \%$ (42 out of 54) of RA subjects and in 91.7\% (22 out of 24) of the apparently healthy individuals. Heterozygous genotype GA was detected in $22.2 \%$ (12 out of 54) of RA patients and $8.3 \%$ ( 2 out of 24 ) of healthy individuals. Distribution of the GA and GG genotypes between RA patients and healthy individuals was not statistically significant (Table 1).

\subsection{Frequencies of Allele Carriage}

For the frequency of A allele carriage, i.e. the proportion of subjects in the two groups carrying at least one A allele, $22.2 \%$ of RA patients carried the A allele compared to $8.3 \%$ of healthy individuals and the difference seemed to be statistically non-significant with Chi square test $(p=0.14)$.

\subsection{Semi-Quantitative Measurement of TNF-a Gene Expression}

To compare the expression of TNF- $\alpha$ mRNA in Egyptian RA patients and the apparently healthy individuals, 14 samples from RA patients and 7 samples from healthy subjects were selected for investigation with semi-quantitative PCR. A primer pair was designed specifically to amplify the TNF- $\alpha$ cDNA and used to compare TNF- $\alpha$ mRNA expression relative to GAPDH mRNA expression. In the majority of samples, relative expression of TNF- $\alpha$ mRNA in RA patients was higher than its relative expression in healthy subjects (Fig.2). The mean value of relative TNF- $\alpha$ mRNA expression in the 14 RA patients was $84 \%$ compared to $76 \%$ in the 7 healthy subjects. This difference was statistically significant by $\mathrm{T}$ - test $(\mathrm{p}=0.0001)$.

A

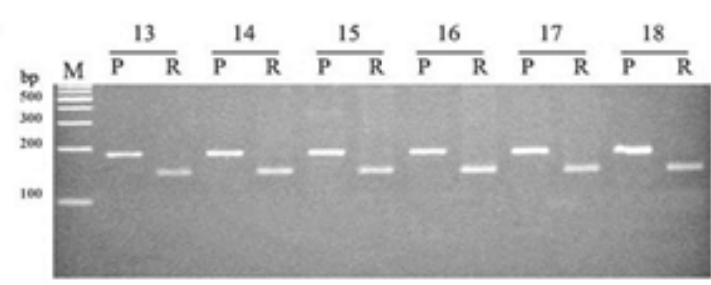

B

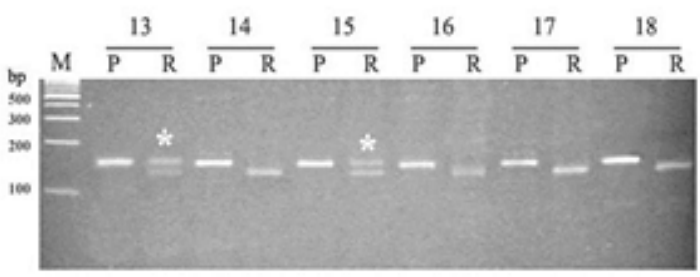

Table 1. Distribution of the different -238 G/A genotypes in RA patients and healthy subjects. $x^{2}$ indicates Chi Square value.

\begin{tabular}{lllllll}
\hline \multirow{2}{*}{ Genotype } & \multicolumn{2}{l}{ RA Patients } & \multicolumn{2}{c}{ Healthy subjects } & \multirow{2}{*}{$\mathbf{2}$} & \multirow{2}{*}{ Sig. } \\
\cline { 2 - 5 } & $\mathbf{N}=\mathbf{5 4}$ & $\mathbf{\%}$ & $\mathbf{N}=\mathbf{2 4}$ & $\mathbf{\%}$ & & \\
\hline GG & 42 & $77.8 \%$ & 22 & $91.7 \%$ & 2.18 & 0.14 \\
GA & 12 & $22.2 \%$ & 2 & $8.3 \%$ & 2.18 & 0.14 \\
AA & 0 & $0.0 \%$ & 0 & $0.0 \%$ & - & - \\
\hline
\end{tabular}

\section{Discussion}

There is a great deal of evidence that points to the contribution of TNF- $\alpha$ gene as a common genetic factor in the pathogenesis of diseases caused by inflammatory and/or autoimmune etiologies [17]. Production of TNF- $\alpha$ is thought to be controlled by genetic polymorphisms in the genes regulating its production and effect [15]. Also, single-nucleotide polymorphisms (SNPs) in the TNF- $\alpha$ gene itself have a functional significant role in the regulation of its production as there are many SNPs within the TNF- $\alpha$ gene promoter [18]. Genetically controlled production of TNF- $\alpha$ leads to differences in its synthesis; which in turn could imply the influence of TNF- $\alpha$ polymorphism on RA susceptibility or severity [9]. In the current study, no polymorphism was recorded in the site -376 neither in RA patients nor in the apparently healthy individuals. This indicates the wide distribution of the wild type GG genotype among Egyptians. These data are in agreement with that of Barton et al. [19] who found no difference in either allele or genotype frequencies at the position -376 between RA patients developing erosions and those remaining non erosive at 5 years. Several TNF- $\alpha$ polymorphism $(-857,-376$, -308 , and -238 ) as well as the +489 exonic SNP have been studied to investigate its association with susceptibility to, or severity of RA and some of these studies [20-26] revealed no association but the association was approved in some others $[27,28]$.
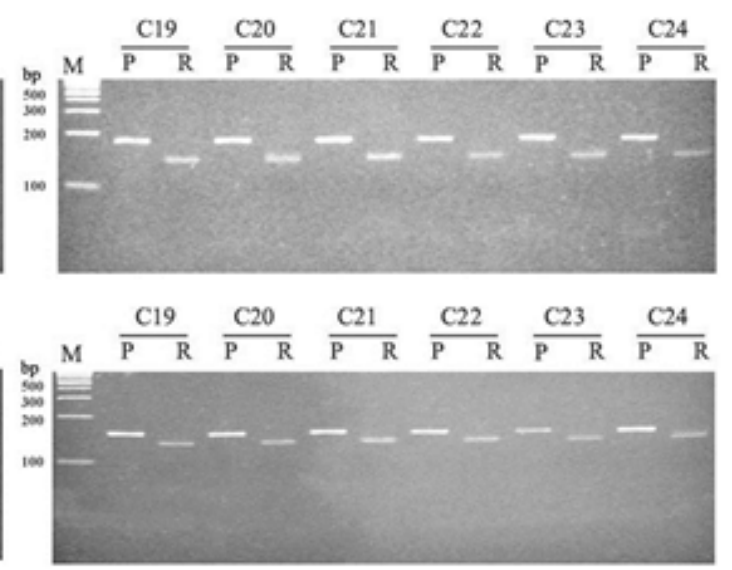

Figure 1. Representative gels showing the restriction digestion pattern with FokI and MspI. Row A shows restriction pattern with FokI for investigating -376 G/A polymorphism. Row B shows restriction pattern with MspI for investigating -238 G/A polymorphism. Left gels show RA samples 13-18 and right gels show samples 19-24 from healthy individuals. Lanes " $P$ " refer to undigested PCR products while lanes " $R$ " refer to digested PCR products. * indicates the genotype GA.

For the $-238 \mathrm{G} / \mathrm{A}$ polymorphism, our data indicated that, $77.8 \%$ of RA patients were of the genotype GG and $22.2 \%$ were heterozygous (GA). But for the apparently healthy individuals, $91.7 \%$ were of the genotype GG and $8.3 \%$ were 
heterozygous (GA). In both types of subjects, the homozygous genotype AA was not recorded at all.

There are several inconsistent data about this polymorphism. The study of Ozen et al. [29] on Turkish RA subjects approved that the distributions of allele frequencies of $-238 \mathrm{G} / \mathrm{A}$ and $-308 \mathrm{G} / \mathrm{A}$ polymorphisms were not significantly different from those of controls. The same study also showed that $-238 \mathrm{G} / \mathrm{A}$ and $-308 \mathrm{G} / \mathrm{A}$ polymorphisms in the promoter region of TNF- $\alpha$ were not different from those of control which is in agreement with our results. The authors concluded that these two polymorphisms were not a defining factor for the development of RA disease.

Tsunemi et al. [30] and Epplen et al. [31] observed no association between TNF- $\alpha-238$ polymorphism and psoriasis, while the association between this polymorphism and psoriatic arthritis in several populations has been reported in several studies [32-40].

On the other hand, some studies have shown an association of the -238 GG genotype with worse RA prognosis [21, 23, 41, 42]. The TNF -238 GA genotype is thought to correlate with less severe disease in multiple sclerosis [43].

For allele distribution, this study did not record any significance in either the $G$ or A allele distribution between the RA group and the group of healthy subjects. The $\mathrm{G}$ allele was recorded in $100 \%$ of both groups, while the A allele was recorded in $22 \%$ of the RA patients and in $8.3 \%$ of healthy individuals and this difference was statistically non-significant $(p=0.14)$. Brinkman et al. [23] recorded a slight over representation of the $-308 \mathrm{G}$ and $-238 \mathrm{G}$ alleles in RA, but this increase was not significantly different from its distribution in healthy individuals. Some other reports have associated both the $-238 \mathrm{~A}$ and $-238 \mathrm{G}$ allelic forms to high TNF- $\alpha$ production but with clearly contrasting results $[43$, 44].

$-238 \mathrm{G} / \mathrm{A}$ TNF- $\alpha$ polymorphism has been reported to be associated with other diseases. In systemic lupus erythematosus, the TNF- $\alpha-238$ AA genotype was found to be a marker of a particular clinical subtype [45]. This polymorphism was also associated with the occurrence of scarring thrachoma [46] and susceptibility to alcoholic steatohepatitis [47]. According to Jang et al. [48], -238 G/A polymorphism had an apparently protective role against a range of tumors. This polymorphism was also associated with clinical characteristics of chronic hepatitis $\mathrm{C}$ according to Hohler et al. [49] and Dai et al. [50].

In the current study, no association was detected between either $-376 \mathrm{G} / \mathrm{A}$ or $-238 \mathrm{G} / \mathrm{A}$ polymorphisms and RA in Egyptian patients. It has been reported that in the promoter area linkage disequilibrium is strong and that it may be difficult to study the role of SNPs in isolation [9]. Knight et al. [51] indicated that the $-376 \mathrm{~A}$ allele is in allelic association with the $-308 \mathrm{G}$ and -238 A alleles in Caucasian population. Therefore, further studies on the $-308 \mathrm{G} / \mathrm{A}$ polymorphism could confirm or negate this finding in Egyptian patients. It is noteworthy to mention that Mosaad et al. [15] demonstrated an association of the TNF- $\alpha-308 \mathrm{G}$ allele and GG homozygous genotype with susceptibility to RA and the presence of the A allele with erosion in the patients.

Semi-quantitative PCR on some RA samples in this study revealed a significant increase in the relative expression of TNF- $\alpha$ mRNA in RA patients compared to healthy subjects. This is in agreement with the study of Nemec et al. [9] which indicated high concentrations of TNF- $\alpha$ in serum and synovial fluid of RA patients and indicated a correlation between the TNF- $\alpha$ blood concentration and disease activity.

Thus, the current data implement the absence of an association between the $-376 \mathrm{G} / \mathrm{A}$ or $-238 \mathrm{G} / \mathrm{A}$ polymorphisms and the increased expression of TNF- $\alpha$ in RA patients. Kaijzel et al. [42] hypothesized that the $-238 \mathrm{G}$ to A transition might influence TNF- $\alpha$ mRNA expression and as a result facilitates deregulation of the cytokine network, thereby influencing the disease process. However, the results of the current study are supported by in vitro transfection assays which indicated that TNF -238 A by itself or in combination with TNF -376 A is not likely to be of direct functional relevance for transcriptional activation. Therefore, these polymorphisms were thought to serve as markers for additional polymorphisms in the TNF/LT locus or neighboring genes that may influence disease severity [42]. It is still possible that the high expression of TNF- $\alpha$ in RA patients could be controlled by other polymorphisms in its promoter (e.g. $-308 \mathrm{G} / \mathrm{A}$ ) or the genetic polymorphisms in the genes regulating its production [15].

Study of TNF- $\alpha$ polymorphisms among Egyptians is limited with only a single study by Mosaad et al. [15] on $-308 \mathrm{G} / \mathrm{A}$ polymorphism. Up to the best of our knowledge and based on the published literature, this is the first study to address the association between RA and $-376 \mathrm{G} / \mathrm{A}$ and -238 G/A polymorphisms of TNF- $\alpha$ in Egyptian patients.

Based on the results of the current study it can be concluded that Egyptian RA patients may have different genetic or environmental factors contributing to the pathogenesis of RA. Further studies are necessary to search for other genetic polymorphisms and/or genes that contribute to the increased expression of TNF- $\alpha$ and hence the pathogenesis of RA in Egyptian patients.

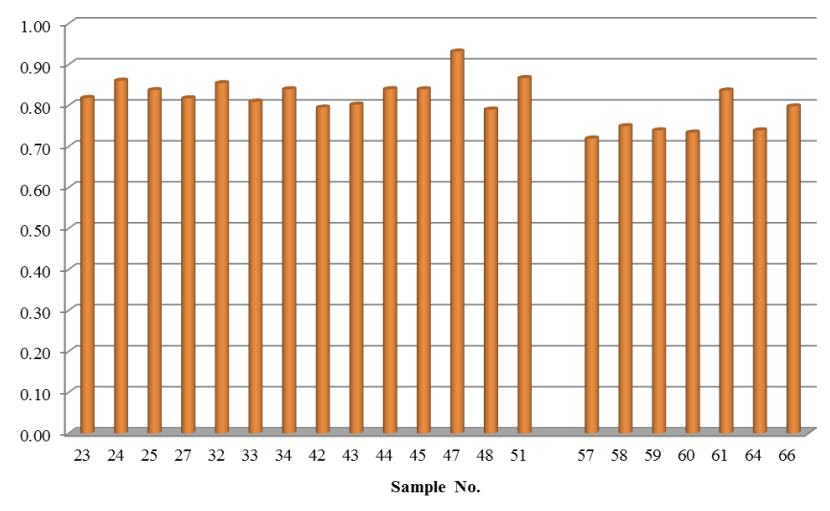

Figure 2. Relative expression of $T N F-\alpha$ in 14 rheumatoid arthritis patients (23-51) and 7 healthy individuals (57-66). 


\section{Acknowledgements}

The authors would like to thank Radwa El-Tahan, a graduate student in Zoology Department, Faculty of Science, Damietta University, for her assistance in lab work.

\section{References}

[1] E. Choy, "Understanding the dynamics: pathways involved in the pathogenesis of rheumatoid arthritis," Rheumatology, vol. 51, pp. 3-11, 2012.

[2] Centers for Disease Control and Prevention. Rheumatoid arthritis. www.cdc.gov/arthritis/basics/rheumatoid.htm.

[3] Arthritis Foundation. News from the Arthritis Foundation: Rheumatoid Arthritis Fact Sheet. 2008. www.arthritis.org/files/images/newsroom/media-kits/Rheumat oid_Arthritis_Fact_Sheet.pdf.

[4] C. S. Crowson, E. L. Matteson, E. Myasoedova, C. J. Michet, F. C. Ernste, K. J. Warrington, J. M. Davis III, G. G. Hunder, T. M. Therneau, and S. E. Gabriel, "The Lifetime Risk of Adult-Onset Rheumatoid Arthritis and Other Inflammatory Autoimmune Rheumatic Diseases," Arthritis Rheum., vol. 63, pp. 633-639, 2011.

[5] J. D. Reveille, "The genetic contribution to the pathogenesis of rheumatoid arthritis," Curr. Opin. Rheumatol., vol. 10, pp. $187-200,1998$.

[6] J. S. Smolen, and G. Steiner, "Therapeutic strategies for rheumatoid arthritis," Nat. Rev. Drug Discov., vol. 2, pp. 473-88, 2003.

[7] J. S. Smolen, D. Aletaha, M. Koeller, M. H. Weisman, and P. Emery, "New therapies for treatment of rheumatoid arthritis," Lancet, vol. 370, pp. 1861-74, 2007.

[8] F. M. Brennan, R. N. Maini, and M. Feldmann, "TNF alpha-a pivotal role in rheumatoid arthritis?," Br. J. Rheumatol., vol. 31, pp. 293-298, 1992.

[9] P. Nemec, P. Monika, S. Martina, V. Anna, S. Miroslav, and G. Jindra, "Polymorphism in the tumor necrosis factor- $\alpha$ gene promoter is associated with severity of rheumatoid arthritis in the Czech population," Clin. Rheumatol., vol. 27, pp. 59-65, 2008.

[10] M. W. Van der Linden, T. W. Huizinga, D. J. Stoeken, A. Sturk, and R. G. Westendorp, "Determination of tumour necrosis factor-alpha and interleukin-10 production in a whole blood stimulation system: assessment of laboratory error and individual variation," J. Immunol. Methods, vol. 218, pp. 63-71, 1998.

[11] J. P. Bayley, T. H. Ottenhoff, and C. L. Verweij, "Is there a future for TNF promoter polymorphisms?" Genes Immun., vol. 5, pp. 315-329, 2004

[12] C. L. Verweij, "Tumour necrosis factor gene polymorphisms as severity markers in rheumatoid arthritis," Ann. Rheum. Dis., vol. 58, pp. I20-I26, 1999.

[13] N. de Vries, and P. P. Tak, "The response to anti-TNF-alpha treatment: gene regulation at the bedside," Rheumatology, vol. 44, pp. 705-707, 2005.

[14] J. E. Fonseca, T. Carvalho, M. Cruz, P. Nero, M. Sobral, A.F. Mourão, J. Cavaleiro, D. Ligeiro, I. Abreu, M. Carmo-Fonseca, and J.C. Branco, "Polymorphism at position -308 of the tumour necrosis factor alpha gene and rheumatoid arthritis pharmacogenetics," Ann. Rheum. Dis., vol. 64, pp. 793-794, 2005.

[15] Y. M. Mosaad, A. Abdelsalam, and S. R. El-bassiony, "Association of tumour necrosis factor-alpha -308 G/A promoter polymorphism with susceptibility and disease profile of rheumatoid arthritis," International Journal of Immunogenetics, vol. 38, pp. 427-433, 2011.

[16] K. M. Moukhtar, A. M. Ghoneim, N. El-Mashad, E. M. Hammad, and O Abu Samak, "Investigation of the genetic polymorphism of interleukin-10 gene in rheumatoid arthritis patients in Egypt," World Journal of Medical Sciences, vol. 10, pp. 319-325, 2014.

[17] S. Jimenez-Morales, R. Velàzquez-Cruz, J. Ramırez-Bello, E. Bonilla-Gonzalez, S. Romero-Hidalgo, G. Escamilla-Guerrero, F. Cuevas, F. Espinosa-Rosales, N. E. Martínez-Aguilar, J. Gómez-Vera, V. Baca, and L Orozco, "Tumor necrosis factor-alpha is a common genetic risk factor for asthma, juvenile rheumatoid arthritis, and systemic lupus erythematosus in a Mexican pediatric population," Human Immunology, vol. 70, pp. 251-256, 2009.

[18] M. M. Elahi, K. Asotra, B. M. Matata, and S. S. Mastana, "Tumor necrosis factor alpha -308 gene locus promoter polymorphism: an analysis of association with health and disease," Biochimica et Biophysica Acta, vol. 1792, pp. 163-172, 2009.

[19] A. Barton, H. Platt, F. Salway, D. Symmons, E. Barrett, M. Bukhari, M. Lunt, E. Zeggini, S. Eyre, A. Hinks, D. Tellam, B. Brintnell, W. Ollier, J. Worthington, and A. Silman, "Polymorphisms in the tumour necrosis factor gene are not associated with severity of inflammatory polyarthritis," Ann. Rheum. Dis., vol. 63, pp. 280-284, 2004.

[20] N. Seki, S. Kamizono, A. Yamada, T. Higuchi, H. Matsumoto, F. Niiya, A. Kimura, K. Tsuchiya, R. Suzuki, Y. Date, T. Tomita, K. Itoh, and T. Ochi, "Polymorphisms in the 59-flanking region of tumor necrosis factor-alpha gene in patients with rheumatoid arthritis," Tissue Antigens, vol. 54, pp. 194-7, 1999.

[21] J. Vinasco, Y. Beraun, A. Nieto, A. Fraile, L. Mataran, E. Pareja, and J. Martín, "Polymorphism at the TNF loci in rheumatoid arthritis," Tissue Antigens, vol. 49, pp. 74-8, 1997.

[22] J. H. Yen, C. J. Chen, W. C. Tsai, C. H. Lin, T. T Ou, C. C. Wu, and $\mathrm{H}$. W. Liu, "Tumor necrosis factor promoter polymorphisms in patients with rheumatoid arthritis in Taiwan," J. Rheumatol., vol. 28, pp. 1788-92, 2001.

[23] B. M. Brinkman, T. W. Huizinga, S. S. Kurban, E. A. van der Velde, G. M. Schreuder, J. M. Hazes, F. C. Breedveld, and C. L. Verweij, "Tumour necrosis factor alpha gene polymorphisms in rheumatoid arthritis: association with susceptibility to, or severity of, disease?," Br. J. Rheumatol., vol. 36, pp. 516-21, 1997.

[24] J. K. Lacki, R. Moser, I. Korczowska, S. Mackiewicz, and W. Muller, "TNF-alpha gene polymorphism does not affect the clinical and radiological outcome of rheumatoid arthritis," Rheumatol. Int., vol. 19, pp. 137-40, 2000.

[25] M. Field, G. Gallagher, J. Eskdale, F. McGarry, S. D. Richards, R. Munro, H. H. Oh, and C Campbell, "Tumor necrosis factor locus polymorphisms in rheumatoid arthritis," Tissue Antigens, vol. 50, pp. 303-7, 1997. 
[26] A. S. Low, M. A. Gonzalez-Gay, M. Akil, R.S. Amos, D. E. Bax, C. Cannings, A. Hajeer, S. H. Till, J. Winfiel, W. E. Ollier, and A. G. Wilson, "TNF +489 polymorphism does not contribute to susceptibility to rheumatoid arthritis," Clin. Exp. Rheumatol., vol. 20, pp. 829-32, 2002.

[27] M. V van Krugten, T. W. Huizinga, E. L. Kaijzel, E. Zanelli, K. W. Drossaers-Bakker, L. P. van de Linde, J. M. Hazes, A. H. Zwinderman, F. C. Breedveld, and C. L. Verweij, "Association of the TNF +489 polymorphism with susceptibility and radiographic damage in rheumatoid arthritis," Genes Immun., vol. 1, pp. 91-6, 1999.

[28] F. Waldron-Lynch, C. Adams, C. Amos, D. K. Zhu, M. F. McDermott, F. Shanahan, M. G. Molloy, and F. O'Gara, "Tumour necrosis factor alpha promoter single nucleotide polymorphisms influence susceptibility to rheumatoid arthritis (RA) in immuno genetically defined multiplex RA families," Genes, vol. 2, pp. 82-7, 2001.

[29] S. Ozen, M. Alikasifoglu, A. Bakkaloglu, A. Duzova, K. Jarosova, D. Nemcova, N. Besbas, J. Vencovsky, and E. Tuncbilek, "Tumor necrosis factor alpha G-A -238 and G-A -308 polymorphism in Juvenile idiopathic arthritis," Rheumatology, vol. 41, pp. 223-227, 2002.

[30] Y. Tsunemi, A. Nishibu, H. Saeki, N. Oyama, K. Nakamura, M. Kishimoto, H. Mitsui, Y. Tada, H. Torii, M. Komine, A. Asahina, F. Kaneko, and K. Tamaki, "Lack of association between the promoter polymorphisms at positions -308 and -238 of the tumor necrosis factor alpha gene and psoriasis vulgaris in Japanese patients," Dermatology, vol. 207, pp. $371-4,2003$.

[31] C. Epplen, H. Rumpf, E. Albert, P. Haas, H. Truckenbrodt, and J. T. Epplen, "Immunoprinting excludes many potential susceptibility genes as predisposing to early onset pauciarticular juvenile chronic arthritis except HLA Class II and TNF," Eur. J Immunogent., vol. 22, pp. 311-322, 1995.

[32] A. I. Arias, B. Giles, T. H. Eiermann, W. Sterry, and J. P. Pandey, "Tumor necrosis factor- alpha gene polymorphism in psoriasis," Exp. Clin. Immunogenet, vol. 14, pp. 118-22, 1997.

[33] H. Schmeling, U. Wagner, A. Peterson, and G. Horneff, "Tumor necrosis factor alpha promoter polymorphisms in patients with juvenile idiopathic arthritis," Clinical and Experimental Rheumatology, vol. 24, pp. 103-108, 2006.

[34] T. Hohler, S. Grossmann, B. Stradmann-Bellinghausen, W. Kaluza, E. Reuss, K. deVlam, E. Veys, and E. Märker-Hermann, "Differential association of polymorphisms in the TNFa region with psoriatic arthritis but not psoriasis," Ann. Rheum. Dis., vol. 61, pp. 213-18, 2002.

[35] T. Hohler, A. Kruger, P. M. Schneider, R. E. Schopf, J. Knop, C. Rittner, K. H. Meyerzum Büschenfelde, and E. Märker-Hermann, "A TNF- alpha promoter polymorphism is associated with juvenile onset psoriasis and psoriatic arthritis," J. Invest. Dermatol., vol. 109, pp. 562-5, 1997.

[36] A. M. Al-Heresh, J. Proctor, S. M. Jones, J. Dixey, B. Cox, K. Welsh, and N. McHugh, "Tumour necrosis factor-alpha polymorphism and the HLA-Cw*0602 allele in psoriatic arthritis," Rheumatology, vol. 41, pp. 525-30, 2002.

[37] J. Balding, D. Kane, W. Livingstone, L. Mynett-Johnson, B. Bresnihan, O. Smith, and O. FitzGerald, "Cytokine gene polymorphisms: association with psoriatic arthritis susceptibility and severity," Arthritis Rheum., vol. 48, pp. 1408-13, 2003.
[38] S. Gonzalez, C. Brautbar, J. Martinez-Borra, A. Lopez-Vazquez, R. Segal, M. A. Blanco-Gelaz, C. D. Enk, C. Safriman, and C. López-Larrea, "Polymorphism in MICA rather than HLA-B/C genes is associated with psoriatic arthritis in the Jewish population," Hum. Immunol., vol. 62 , pp. 632-8, 2001

[39] S. Gonzalez, J. Martinez-Borra, A. Lopez-Vazquez, S. Garcia-Fernandez, J. C. Torre-Alonso, and C. Lopez-Larrea, "MICA rather than MICB, TNFa, or HLA-DRB1 is associated with susceptibility to psoriatic arthritis," J. Rheumatol. Vol. 29, pp. 973-8, 2002.

[40] P. Rahman, F. Siannis, C. Butt, V. Farewell, L. Peddle, F. Pellett, and D. Gladman, "TNFa polymorphisms and risk of psoriatic arthritis," Ann. Rheum. Dis., vol. 65, pp. 919-923, 2006.

[41] M. Fabris, P. E. Di, A. D'Elia, G. Damante, L. Sinigaglia, and G. Ferraccioli, "Tumor necrosis factor- $\alpha$ gene polymorphism in severe and mild-moderate rheumatoid arthritis," J. Rheumatol., vol. 29, pp. 29-33, 2002.

[42] E. L. Kaijzel, M. V. van Krugten, B. M. Brinkman, T. W. Huizinga, T. van der Straaten, J. M. Hazes, H. W. Ziegler-Heitbrock, S. A. Nedospasov, F. C. Breedveld, and C. L. Verweij, "Functional analysis of a human tumor necrosis factor alpha (TNF-alpha) promoter polymorphism related to joint damage in rheumatoid arthritis," Mol. Med., vol. 4, pp. 724-33, 1998.

[43] T. W. J. Huizinga, R. G. J. Westendorp, E. L. E. M. Bollen, V. Keijsers, B. M. Brinkman, J. A. Langermans, F. C. Breedveld, C. L. Verweij, L. van de Gaer, L. Dams, J. B. Crusius, A. García-Gonzalez, B. W. van Oosten, C. H. Polman, and A. S. Peña, "TNF-a polymorphisms, production and susceptibility to multiple sclerosis in different groups of patients," J. Neuro. immunol., vol. 72, pp. 149-153, 1997.

[44] F. Pociot, A. D'Alfonso, S. Compasso, R. Scorza, and P. M. Richiardi, "Functional analysis of a new polymorphism in the human TNF alpha gene promoter," Scand J. Immunol., vol. 42, pp. 501-504, 1995.

[45] S. D'Alfonso, and P. M. Richiardi, "An intragenic polymorphism in the human tumor necrosis factor alpha (TNFA) chain-encoding gene," ImmunoGenetics, vol. 44, pp. 321-322, 1996

[46] D. J. Conway, M. J. Holland, R. L. Bailey, A. E. Campbell, O. S. Mahdi, R. Jennings, E. Mbena, and D. C. Mabey, "Scarring trachoma is associated with polymorphism in the tumor necrosis factor alpha (TNF-a) gene promoter and with elevated TNF-a levels in tear fluid," Infection Immunity, vol. 65, pp. 1003-1006, 1997.

[47] J. Grove, A. K. Daly, M. F. Bassendine, and C. P. Day, "Association of a tumor necrosis factor promoter polymorphism with susceptibility to alcoholic steatohepatitis," Hepatology, vol. 26, pp. 143-146, 1997.

[48] W. H. Jang, Y. I. Yang, S. S. Yea, Y. J. Lee, J. H. Chun, H. I. Kim, M. S. Kim, and K. H. Paik, "The -238 tumor necrosis factor-alpha promoter polymorphism is associated with decreased susceptibility to cancers," Cancer Lett., vol. 166, pp. 41-46, 2001.

[49] T. Hohler, A. Kruger, G. Gerken, P. M. Schneider, K. H. Meyerzum Büschenfelde, and $\mathrm{C}$ Rittner, "Tumor necrosis factor alpha promoter polymorphism at position -238 is associated with chronic active hepatitis C infection," J. Med. Virol., vol. 54, pp. 173-7, 1998. 
[50] C. Y. Dai, W. L. Chuang, L. P. Lee, S. C. Chen, N. J. Hou, Z. Y. Lin, M. Y. Hsieh, M. Y. Hsieh, L. Y. Wang, W. Y. Chang, and M. L. Yu, "Associations of tumour necrosis factor alpha promoter polymorphisms at position -308 and -238 with clinical characteristics of chronic hepatitis C," J. Viral Hepat., vol. 13 , pp. 770-4, 2006.
[51] J. C. Knight, I. Udalova, A. V. Hill, B. M. Greenwood, N. Peshu, K. Marsh, and D. Kwiatkowski, "A polymorphism that affects OCT-1 binding to the TNF promoter region is associated with severe malaria," Nat. Genet., vol. 22, pp. 145-150, 1999. 